Article

\title{
Ecofeminism and Natural Resource Management: Justice Delayed, Justice Denied
}

\author{
Yang Liu ${ }^{1,2}$, Muhammad Khalid Anser ${ }^{3, *}$ and Khalid Zaman ${ }^{4, *}$ \\ 1 School of Economics, Xi'an University of Finance and Economics, Xi'an 710100, China; yangl@xaufe.edu.cn \\ 2 School of Economics, Nankai University, Tianjin 300071, China \\ 3 School of Public Administration, Xi'an University of Architecture and Technology, Xi'an 710054, China \\ 4 Department of Economics, University of Haripur, Khyber Pakhtunkhwa, Haripur 22620, Pakistan \\ * Correspondence: mkhalidrao@xauat.edu.cn (M.K.A.); khalid_zaman786@yahoo.com (K.Z.)
}

Citation: Liu, Y.; Anser, M.K.; Zaman, K. Ecofeminism and Natural Resource Management: Justice Delayed, Justice Denied. Sustainability 2021, 13, 7319. https://doi.org/ $10.3390 /$ su13137319

Academic Editor: Rajesh Kumar Jyothi

Received: 16 May 2021

Accepted: 24 June 2021

Published: 30 June 2021

Publisher's Note: MDPI stays neutral with regard to jurisdictional claims in published maps and institutional affiliations.

Copyright: (c) 2021 by the authors. Licensee MDPI, Basel, Switzerland. This article is an open access article distributed under the terms and conditions of the Creative Commons Attribution (CC BY) license (https:// creativecommons.org/licenses/by/ $4.0 /)$.

\begin{abstract}
Women have a right to excel in all spheres of activity. However, their roles are mainly confined in the resource extraction industry due to masculinity bias. African women are considered exemplary cases where women have low access to finance and economic opportunities to progress in the natural resource industry. This study examines the role of women's autonomy in mineral resource extraction by controlling ecological footprints, financial development, environmental degradation, economic growth, and changes in the general price level in the Democratic Republic of the Congo data from 1975-2019. The autoregressive distributed lag estimates show that in the short-run, women's autonomy decreases mineral resource rents; however, this result disappears in the long-run and the positive role of women's autonomy in increasing resource capital is confirmed. Ecological footprints are in jeopardy from saving mineral resources both in the short- and long-term. Financial development negatively impacts mineral resource rents, while women's access to finance supports the mineral resource agenda. The positive role of women in environmental protection has led to increased mineral resource rents in the short- and long-term. Women's social and economic autonomy increases mineral resource rents in the short-term, while it has evaporated in the longterm. The Granger causality has confirmed the unidirectional linkages running from women's green ecological footprints, access to finance, and women participating in environmental protection to mineral resource rents in a country. The variance decomposition analysis has shown that women's economic autonomy and access to finance will exert more significant variance shocks to mineral resource rents over the next ten years' period. The results conclude the positive role of women's freedom in the mineral resource sustainability agenda. Thus, there is a high need to authorize women through access to finance and economic decisions to restore natural resource capital nationwide.
\end{abstract}

Keywords: ecological footprints; mineral resource rents; women's autonomy; financial development; environmental protection; Congo Democratic Republic

\section{Introduction}

Extractive industries have played a vital role in promoting economic development by providing resource inputs to the industries to produce commodity products and export them to the foreign market [1]. More than $60 \%$ of the women in abundant resource economies directly contact the resource market and depend upon it to satisfy their families' basic needs [2]. Sub-Saharan Africa (SSA) is no exception, and is endowed with natural resources, including mineral resources, gas, and oil reserves used to export as primary goods and balance its national account [3]. On the other hand, there are fewer opportunities for women in this sector to decently sustain their lives. Women are more exploited and sexually harassed during their lifetime [4]. Physical and sexual violence is common, which has sabotaged the United Nations sustainable development goal-SDG-5. Worldwide, up to $50 \%$ of the girls under 16 are sexually assaulted. Around 150 million girls under the 
age of 18 have suffered from some form of sexual violence. About 130 million women and girls have experienced female genital cutting, while more than 3 million remain at risk annually in Africa. The child bride's victimization remains higher in South Asia and the SSA region, where girls are married younger than adolescent age. Approximately $30 \%$ to $40 \%$ of women have suffered sexual harassment at their workplace in some Asian countries, including the Philippines, Japan, South Korea, and Malaysia, while it is 20\% in Nairobi. More than 200,000 women and girls have faced sexual violence annually in the Congo [5].

The Democratic Republic of the Congo (DRC) is in Central Africa, the largest SSA region by its covering geographical area and 11th largest country. Despite its importance in its area coverage, the country has primarily suffered from high poverty rates. The country's poverty headcount ratio is the 3rd highest globally, exceeding $80 \%$ poverty in the northwest, while more than $50 \%$ of poverty remains in Kinshasa and Lubumbashi cities. Further, the fifth-largest amount of poor people reside within its borders. The super hyperinflation is one cause, that is around $65 \%$ in the rural zones, $63 \%$ in the urban zones, and around $80 \%$ in the small towns. Most cities and towns are labor-intensive and capital-scarce due to poor connectivity with the other cities with high unemployment rates. Based on this vulnerable estimate, the country has ranked at the bottom of its human development index [6]. Gender-based violence is another factor that is the root cause of all evils. The country remains affected by conflicts, food security issues, and spreading epidemics that increase social evils $[7,8]$.

Gender equality is the fundamental human right that helps build the nation to be more peaceful, prosperous, civilized, and healthy. The nations should strive hard to favor gendering policies to control gender-based violence, provide social justice and protection, and give equal employment opportunities without discrimination. Women should be involved in their healthcare decision-making process that can empower women in every walk of life $[9,10]$. To achieve the stated targets of SDG-5, it is high time to unlock women's potential through technical skills-based training and investment in women to participate in economic decisions [11]. The earlier literature is available on the United Nations SDG-5 in different socio-economic and environmental settings. However, there is still vacant room for policy implications and effectiveness of sustainable policies to culminate different forms of women exploitation across the globe. This study explicitly evaluates women's role in the mining sector by controlling social, economic, and environmental factors. The literature is divided into three different streams, which are presented as follows:

\subsection{The Literature on Different Forms of Women Exploitation in the Mining Sector}

Women, in general, are exploited in various ways during their life. It is not confined to sexual and physical harassment, as in many parts of the civilized world, women tend to be exploited by locking their potential to progress in the job market. Botha [12] concluded that women in the African mining sector need special attention to get equal employment opportunities and mining regulations to support them in their working environment. Women have faced many unprecedented challenges and barriers that lead them to socio-economic and environmental obstructions, which have negatively affected women's autonomy. The need for gender equality-based policies is imperative for empowering women in the mining sector. Pactwa [13] argued that women's mining jobs are minimal and ordinary, as working in mines remains to be considered as having a masculinity factor. Hence, the mining sector's career growth is very restricted, and only a few women reached the top hierarchy of the management. Women are greater in number pursuing their higher studies in the related fields of mining, while they face a severe challenge of acquiring a decent job in the mining sector. The high need is to accommodate women by offering internship and apprenticeship schemes, capable of equipping them with hands-on training and getting a decent job in the resource sector. Mangaroo-Pillay and Botha [4] discussed the number of barriers that women faced in the mining sector of the South African economy, i.e., women are generally working in core mining areas, where it found substantial exploitation to consider them as a sexual object. Further, its protective equipment during working time needs 
more caution for pregnant women to work under safety healthcare standards, as currently, it is not at a standard to support women's health. Inadequate training, work-life balance, unattractive working environment, and negative perceptions about women discriminate against them in their career life. The greater need for handling these issues to give women autonomy in their career growth helps to sustain the resource market to contribute to the country's economic growth. Mugo et al. [14] collected data from 215 women working at different nodes of Kenya's artisanal and small-scale mining sectors and found various forms of gender inequality in this sector. The low-paid, inadequate hands-on-training job, invalid mining permits, social and cultural barriers are a few crucial facts that discriminate against women in the resource market. The stringent gender equality policies to empower women by providing skills-based training and valid permits to work in the mining help them contribute their share in the labor force participation rate, ultimately contributing to an inclusive growth agenda. Bashwira and der Haar [15] discussed different push and pull factors that Congolese women faced intending to join the artisanal mining sector to get security and a degree of freedom. Despite some positive thoughts, women were discriminated against in various ways during the working lives that hurt them and deeply buried their hopes under sexual violence and job insecurity. These lethal challenges are damaging many women's career growth in this sector; few accept these challenges and tackle them through creative leadership skills to create new revenue sources to get them out of these miseries. Orleans-Boham et al. [16] argued that low mineral extraction and processing in Ghana's artisanal mining lead to many unwanted social and environmental hazards that lead to banning this sector. This enactment of the ban increasing the challenges of rising poverty in this sector; as before the ban, unskilled women earned USD 22.22, and skilled women earned USD 44.44 per week that helps them out to escape from the designated World Bank poverty threshold of USD 1.90 per day. The larger share of women in the mining sector's labor force is badly affected and forced to work in some menial jobs that have exacerbated their household sufferings. The technological advancement in the processing and extraction of artisanal mining is the optimal solution to mitigate environmental hazards and enable this sector to work under sustainable mineral resource nodes, ultimately getting more jobs in this sector to get women out of poverty. Reichel [17] argued that easy access to finance in the artisan mineral sector promotes gender equality and formalizes this sector, more enabling technological adjustment to extract mineral resources in a more refined processing way to reduce waste. Based on the given literature, the study formalizes the following hypothesis, i.e.,

Hypothesis 1. The unlocking potential of women is likely to reduce gender inequality and promote the mining sector.

\subsection{The Literature on the Role of Women's Autonomy in Promoting Resource Market through the Decision-Making Process}

Women's freedom in socio, economic, and environmental business led them to promote the resource market. The earlier studies favor women's autonomy that helps them support the country's economic growth. Thankian [18] evaluated different factors that affect women's household decisions in Zambia. For this purpose, the study used the 2013 country's demographic household survey and found that women generally take all major decisions from household affairs while getting limited access to control over economic resources. The study concludes that women empowerment is possible when allowing women to participate equally in the economic agenda to control economic resources that help sustain their lives and get out of them from miseries. Pandey et al. [19] argued that development and market-based intervention are vital for empowering women in the Indian dairy sector under formal political institutions. The study stressed the need to restructure women's social status, empowering them to participate in the decision-making process. Holland and Rommohan [20] discussed the two crucial factors that remain a challenge for the Bangladesh economy, including child food security and women empowerment, as women autonomy in the livelihood sector is the only solution to overcome the child stunt- 
ing problem. Women's unlocking potential to allow speaking in public gives the women confidence to speak for their rights while it substantially links with the higher children's height scores that complement the nutritional supplement. The greater need for reducing child stunting can be possible by empowering women in household decision-making. Further, it improves dietary diversity in a country. Khan [21] conducted the exploratory case study of women's role in business entrepreneurship in the Malakand district in Pakistan's' KPK province. The main hurdles faced by women entrepreneurs are the lack of support of their male family members, low access to market networks, and other social-cultural norms. The female-owned enterprises can successfully run through unlocking women's potential in the public spheres that remain inside the customs. Moreira et al. [22] highlighted the need to interlinked women entrepreneurship and firm's internalization, as this subject matter is relatively un-attention earlier in the academic arena. The study found three main subjective elements through bibliometric analysis under the study's stated theme and found that the subject matter revolves around gender and epistemological position, socio-cultural reasonings for business creation, and motivation and firm performance. The feminist internationalization literature is limited to these three stated themes, which positions women in the entrepreneurial spheres. Based on the stated discussion, the study formalizes another hypothesis, i.e.,

Hypothesis 2. Women's economic autonomy is likely to conserve the resource market by involvement in the decision-making process.

\subsection{The Literature on Women Participation in Environmental Protection}

In general, women have the natural ability to love and care for their natural surroundings where they live. More specifically, women's environmental protection participation in conserving ecological resources is prominent in economic and business spheres. Du et al. [23] argued that due to rapid internal migration in Central China 'left behind' the women in the villages, which need to empower women to participate in the decisionmaking process to utilize natural resources more effectively. Ramstetter and Habersack [24] analyzed the perception and behavior of men and women parliamentarians in Europe about pro-environmental behavior and found that women parliamentarian is more environmentally friendly and can affect their policy decisions environmental security. Thus, the need to refresh environmental policies by governing women in an active role in decisionmaking to mitigate climate change. Birindell et al. [25] considered a panel of 96 listed banks of three different regions, namely, Africa, Europe, and the Middle East, for 2011 to 2016 to assess women's leadership's role in environmental performance banks. The results confirmed the hump-shaped relationship between the bank's women director and sustainability reforms that indicate women's positive signal as a director to lead the bank's payoff through green policies. Di Rienzo and Das [26] confirmed the positive relationship between women's political freedom and environmental quality while reducing corruption in a heterogeneous panel of countries. The result enforced the need to involve women in political decisions that reshaping economic and environmental policies for sustainable growth. Lv and Deng [27] considered a panel of 72 countries to assess women's political autonomy and environmental quality from 1971 through 2012. The results show that women's political empowerment and women's participation in civil society reduce carbon emissions. The need to empower women to involve in the decision-making process helps to achieve sustainability agenda across countries. Allen et al. [28] confirmed that women's role in the energy sector is not limited to redistribute power to the corporate and economic businesses while it improves energy governance matter to use renewable energy transformation globally. Pan et al. [29] collected data of 496 female executives from 524 listed companies working in China's premises to assess women's role in the environmental sustainability agenda. The results show that higher participation of females executives substantially increases corporate profit by conserving environmental resources that confirmed the viability of women empowerment in resource management. Zhou and 
Sun [30] concluded that women are generally more affected by climate change than men due to a lack of political wisdom and ignored policymaking agendas. The need to make policies more gender-specific helps to resilient climate change.

Based on the cited literature, the study proposed another tentative statement, i.e.,

Hypothesis 3. Women's political autonomy is likely to impact the country's environmental quality positively.

\subsection{Research Contribution(s), Research Question(s), and Objectives of the Study}

This study has a significant contribution to settle mining issues by empowering women in the resource market by giving them access to finance to enable women to participate in environmentally-friendly behavior. The earlier studies limited to the following issues that women faced in the mining sector, for instance, occupational cultural issues [31], masculine biased [32], healthcare issues [33], Gender-specific issues [34], sexual harassment [35], women rights [36], and health and wealth issues [37], social capital [38], and food security issues [39]. This study moves forward to explore the unexplored factors by using the following four essential aspects of women's autonomy that previously overlooked in the resource market, i.e., (i) women ecological footprints that lead to green footprints, which helps to conserve mineral resources, (ii) women access to finance that help them to increase their livelihoods by extracting mineral resources through sustainable conservation mechanism, (iii) women natural environmental friendly behavior that help them to participate in environmental protection agenda, and (iv) women role in resource conservation agenda through its economic autonomy. The study also included ecological footprints, money supply, carbon emissions, economic growth, and changes in the price level that impacted mineral resource abundance in the Democratic Republic (DRC). These factors would help assess women's role in the mining sector related to the resource sustainability agenda.

The following research questions have been proposed to evaluate women's role in the mining sector critically. First, do women's ecological footprints, that are naturally green, help to restore mineral resources? This question highlighted an important issue that focused on women's positive role in conserving the resource market. Empowering women is an optimal solution to keep the mining sector by lowering ecological footprints than men. Second, to what extent do women get empowered through easy access to finance to preserve mineral resources? The main obstacle in the resource conservation agenda related to access to financing that is not equally accessible to women as men. Thus, the need to empower women in easy accessibility to the financial sector to advance loans and credit may help sustain their livelihoods, leading to efficient resource management. Finally, does women's economic and environmental autonomy help them participate in environmental protection and resource conservation agendas? There is a rise and fall in carbon emissions due to continued economic growth that negatively impacts its resource conservation agenda. The inclusion of women in the national economic agenda does not help lower carbon emissions while supporting the natural resource market's progress to restore sustainability agenda.

Based on the stated research questions, the study makes the following research objectives, i.e.,

(i) To analyze the different roles of women's autonomy in the mining sector.

(ii) To examine the impact of women's ecological footprints, access to finance, and environmental protection on the mineral resource sector, and

(iii) To observe the role of women's socio-economic autonomy on the resource conservation agenda.

Numerous statistical tests checked these objectives, including the Autoregressive Distributed Lag (ARDL) bounds testing approach, Vector Autoregressive (VAR) Granger causality, and Variance Decomposition Analysis (VDA) - all these tests help them get robust parameter estimates used for sound policy implications. 


\section{Materials and Methods}

The study collected the data from World Bank [40] to use it further for empirical analysis to proposed sound policy implications in favor of women's autonomy in the mining sector for the Democratic Republic of the Congo (CDR). The following variables were used in the analysis, i.e., mineral resource rents, women's autonomy, ecological footprints, broad money supply, carbon emissions, inflation, and GDP per capita. The study estimated four more variables from the stated list of variables to give more analytical wisdom to understand the women's role in the country's mining sector, i.e., women's green ecological footprints and women's assess finance, women participation in environmental protection, and women economic autonomy. The study used the data from 1975-2019 for statistical analysis - the list of variables and their measurement presented in Table 1 for ready reference.

Table 1. List of variables and measurement.

\begin{tabular}{|c|c|c|c|c|c|}
\hline Factors & Variables & Symbol & Measurement & Data Source & Expected Sign \\
\hline \multicolumn{6}{|c|}{ Dependent Variable } \\
\hline Resource Market & Mineral Resource Rents & MRR & $\%$ of GDP & World Bank (2020) & - \\
\hline \multicolumn{6}{|c|}{ Independent Variables } \\
\hline Women Freedom & Women's Autonomy & WA & $\begin{array}{l}\text { Women Business and the Law } \\
\text { Index Score (scale 1-100) }\end{array}$ & World Bank (2020) & Positive \\
\hline Ecological Footprints & Arable Land & $\mathrm{AL}$ & Hectares & World Bank (2020) & Negative \\
\hline Green Footprints & Women Green Footprints & WGF & $\begin{array}{l}\text { The relative contribution of } 10 \text { years } \\
\text { average value of AL into WA }\end{array}$ & Author's Construct & Positive \\
\hline Financial Sector & Broad Money Supply & $\mathrm{BM}$ & $\%$ of GDP & World Bank (2020) & Positive/Negative \\
\hline Green Finance & Women Access to Finance & WAF & $\begin{array}{c}\text { The relative contribution of } 10 \text { years } \\
\text { average value of BM into WA }\end{array}$ & Author's Construct & Positive \\
\hline Environmental Degradation & $\mathrm{CO} 2$ Emissions & $\mathrm{CO} 2$ & Metric tons per capita & World Bank (2020) & Negative \\
\hline Environmental Protection & $\begin{array}{l}\text { Women Participation in } \\
\text { Environmental Protection }\end{array}$ & WPEP & $\begin{array}{l}\text { The relative contribution of } 10 \text { years } \\
\text { average value of } \mathrm{CO} 2 \text { into WA }\end{array}$ & Author's Construct & Positive \\
\hline $\begin{array}{l}\text { Changes in Price } \\
\text { Level- GDP deflator }\end{array}$ & $\begin{array}{c}\text { Women Household } \\
\text { Affairs (Proxy variable) }\end{array}$ & WHA & Annual \% & World Bank (2020) & Negative \\
\hline Economic Growth & GDP per capita & GDPPC & Constant of 2010 US\$ & World Bank (2020) & Positive/Negative \\
\hline $\begin{array}{l}\text { Women Economic } \\
\text { Development }\end{array}$ & $\begin{array}{l}\text { Women's Economic } \\
\text { Autonomy }\end{array}$ & WEA & $\begin{array}{l}\text { The interaction term of } \\
\text { WA } \times \text { GDPPC }\end{array}$ & Author's Construct & Positive \\
\hline
\end{tabular}

The Congo economy is abundant with extensive mineral resources that accommodate nearly around $20 \%$ to $50 \%$ of women in the total population engaged with the mineral extraction sites. Congolese women are deprived and working below the given expected value of life. Women's working index value increases from 23.1 (1975) to 78.8 (2019); however, they are even less accessible to reaching financial sector to advance loans and credit to get out from the miseries - the low participation of women in environmental protection due to inadequate financial resources. Table 2 shows the performance of a few indicators of women's empowerment calculated based on women's autonomy index value.

Table 2. Mean values of women's freedom indicators.

\begin{tabular}{|c|c|c|c|c|}
\hline Time Period & $\begin{array}{c}\text { Average WA Index Value } \\
\text { (Low Autonomy } 1 \text { to High Autonomy 100) }\end{array}$ & Average WGF (Hectares) & $\begin{array}{l}\text { Average WAF } \\
(\% \text { of GDP) }\end{array}$ & $\begin{array}{c}\text { Average WPEP } \\
\text { (Metric Tons per Capita) }\end{array}$ \\
\hline $1975-1984$ & 23.10 & $286,558.4$ & 0.695 & 0.006 \\
\hline 1985-1994 & 24.85 & $269,497.0$ & 0.503 & 0.004 \\
\hline 1995-2004 & 29.98 & $223,482.3$ & 0.170 & 0.001 \\
\hline 2005-2014 & 42.50 & $204,261.1$ & 0.212 & 0.0009 \\
\hline 2015-2019 & 62.50 & $210,976.7$ & 0.102 & 0.0004 \\
\hline
\end{tabular}

Source: World Bank [40] and authors estimation. Note: WA-women's autonomy, WGF-women's green footprints, WAF-women access to finance, WEP-women's environmental protection.

Table 2 shows a ten-year average estimation since 1975-2014 while five years average 
analysis for 2015 to 2019. The average index value of women's freedom shows a substantial increase in women's business and law index scores from 23.1 during 1975-1984 to 62.5 for 2015-2019. Besides the substantial increase in women's index score, they have less access to finance, as their share is considerably decreasing from $0.695 \%$ between 1975 and 1984 to 0.102\% of GDP for 2015-2019. Similarly, the share of women in participation for environmental protection extensively decreases from 0.006 metric tons per capita during 1975-1984 to 0.0004 metric tons per capita for 2015-2019. The given data prove that women leave less ecological footprints than men, as women's footprints substantially decrease from 286558.4 hectares between 1975 and 1984 to 210976.7 hectares for 2015-2019.

Based on the crucial facts in the specific country context, the study developed a theoretical framework for understanding the role of women's freedom in the mining sector. For this purpose, the study takes a four-sector model, where the employer exploits women's rights through wage cuts, poor working conditions, and inadequate healthcare resources. Male employees sexually abuse women in the working environment. The government needs to take specific actions for women's protection.

The current study covered four main specific areas of women empowerment. It includes women sustainable footprints in the mining sector [41], women access to finance [42,43], women participation in minimizing sustainable environmental risks [44], and women economic autonomy in the mining sector [45]. Based on the specific factors, the study constructed women's freedom indicators to assess their role in conserving resource market, i.e.,

(i) Women's Green Ecological Footprints (WGF): Gender differences are mostly visible in different consumption patterns with different carbon footprints. Women are generally environmentally friendly and love to take care of their natural surroundings. Thus, women leave a smaller ecological footprint than males [46,47]. The current study calculated women's ecological footprints based on total ecological footprints relative to women's autonomy index. The average 10-year data of arable land in hectares (a proxy for ecological footprints) relative to the women's autonomy index is used for the years 1975-1984, 1985-1994, 1995-2004, and 2005-2014, while 5-years average data is used for the years 2015-2019, i.e.,

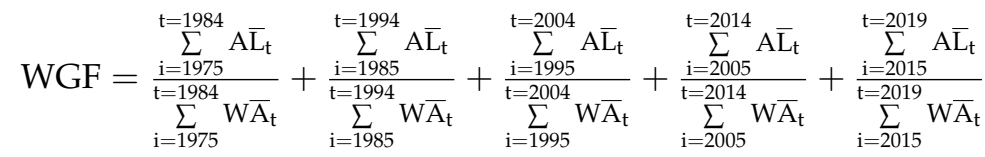

$$
\begin{aligned}
& \therefore \mathrm{A} \overline{\mathrm{L}}=\frac{\sum \mathrm{AL}}{\mathrm{N}}, \mathrm{W} \overline{\mathrm{A}}=\frac{\sum \mathrm{WA}}{\mathrm{N}}
\end{aligned}
$$

where AL shows arable land and WA shows women's autonomy.

(ii) Women's Access to Finance (WAF): The women's role in economic development viewed in the earlier studies, which controlled by financial indicators [48,49], entrepreneurial activities [50], and access to healthcare services [51]. The unlocking of women's potential in extractive industries leads them to optimize resource allocations. The study calculated 10-years and 5-years average value of money supply and women's autonomy index to calculate women access to finance in the mining sector, i.e.,

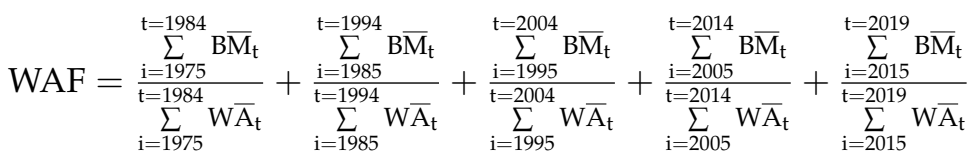

$$
\begin{aligned}
& \therefore \mathrm{B} \overline{\mathrm{M}}=\frac{\sum \mathrm{BM}}{\mathrm{N}}, \mathrm{W} \overline{\mathrm{A}}=\frac{\sum \mathrm{WA}}{\mathrm{N}}
\end{aligned}
$$

(iii) Women's Participation in Environmental Protection (WPEP): Women's role in a sustainable environment is viewed in the resource conservation agenda [52], thus it is 
required to calculate WPEP in terms of carbon emissions and women's autonomy index to access women role in carbon mitigation in the mining sector, i.e.,

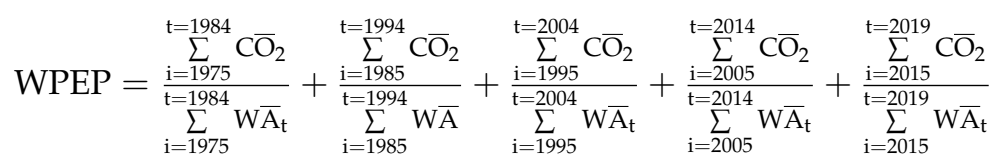

$$
\begin{aligned}
& \therefore \mathrm{CO}_{2}=\frac{\sum \mathrm{CO}_{2}}{\mathrm{~N}}, \mathrm{~W} \overline{\mathrm{A}}=\frac{\sum \mathrm{WA}}{\mathrm{N}}
\end{aligned}
$$

(iv) Women's Economic Autonomy (WEA) refers to a situation where women feel safe and secure in the working environment and household affairs and get autonomy in conserve resource capital. The study calculated this factor by interaction term of country's per capita income and women's autonomy index that gives synergetic impact to assess women role in economic decisions, i.e.,

$$
\mathrm{WEA}=\mathrm{GDPPC} \times \mathrm{WA}
$$

Based on Equations (1)-(4), the study formulated the non-linear regression equation to direct for assessing the role of women empowerment in the mining sector in Congo, i.e.,

$$
\begin{aligned}
& \ln (\mathrm{MRR})_{\mathrm{t}}=\Gamma_{0}+\Gamma_{1} \ln (\mathrm{WA})_{\mathrm{t}}+\Gamma_{2} \ln (\mathrm{AL})_{\mathrm{t}}+\Gamma_{3} \ln (\mathrm{WGF})_{\mathrm{t}}+\Gamma_{4} \ln (\mathrm{BM})_{\mathrm{t}}+\Gamma_{5} \ln (\mathrm{WAF})_{\mathrm{t}}+\Gamma_{6} \ln (\mathrm{CO} 2)_{\mathrm{t}}+ \\
& \Gamma_{7} \ln (\mathrm{WPEP})_{\mathrm{t}}+\Gamma_{8} \ln (\mathrm{CPI})_{\mathrm{t}}+\Gamma_{9} \ln (\mathrm{GDPPC})_{\mathrm{t}}+\Gamma_{10} \ln (\mathrm{WEA})_{\mathrm{t}}+\varepsilon_{\mathrm{t}} \\
& \therefore \frac{\ln (\mathrm{MRR})}{\ln (\mathrm{WA})}>0, \frac{\ln (\mathrm{MRR})}{\ln (\mathrm{AL})}<0, \frac{\ln (\mathrm{MRR})}{\ln (\mathrm{WGF})}>0, \frac{\ln (\mathrm{MRR})}{\ln (\mathrm{BM})}<0, \frac{\ln (\mathrm{MRR})}{\ln (\mathrm{WAF})}>0, \frac{\ln (\mathrm{MRR})}{\ln (\mathrm{CO} 2)}<0, \frac{\ln (\mathrm{MRR})}{\ln (\mathrm{WPEP})}>0, \\
& \frac{\ln (\mathrm{MRR})}{\ln (\mathrm{CPI})}>0, \frac{\ln (\mathrm{MRR})}{\ln (\mathrm{GDPPC})}>0, \frac{\ln (\mathrm{MRR})}{\ln (\mathrm{WEA})}>0
\end{aligned}
$$

Equation (1) shows that women's autonomy, green ecological footprints, access to finance, women's participation in environmental protection, and women's political autonomy are likely to impact the resource conservation agenda positively. In contrast, arable land, money supply, carbon emissions, and continued economic growth would likely cause damaging effects on the mineral resource agenda in a country.

Based on the theoretical expectations of the stated variables on mineral resources, the study formulated the following research hypotheses, i.e.,

Hypothesis 4. Women's autonomy is likely to increase mineral resource rents in a country.

Hypothesis 5. Women access to finance, green ecological footprints, and women's participation in environmental protection is likely to improve resource conservation agenda in a country.

Hypothesis 6. Women's political autonomy is likely to increase resource capital in a country.

The different statistical methods, including, time-series cointegration technique, Granger causality approach, and inter-temporal forecasting technique, evaluated the given hypotheses. The study employed an ADF unit root test widely used in econometric studies to analyze the individual variables' stationary series. The computational procedure gives different patterns of variables movement to get an insight into its integration order. The variables' static properties assess with 'intercept' and 'time trend' at the level and its first difference. The variable stationery at level confirmed the zero-order of integration, while the first difference stationary shows the order of integration. The integration order is as I(0) and I(1) series, respectively. The unit root estimates' integration order helps understand the right statistical technique to get robust parameter estimates. The long-term time series usually get two main order of integration, i.e.,

(i) All the variables have a standard order of integration, and

(ii) The candidate variables have a different integration of order. 
In the first case, if the stated variables exhibit $\mathrm{I}(0)$ properties, then it usually goes for using different regression apparatus, not limited to the following, i.e., ordinary least square regression technique, quantile regression approach, step-wise least square regression, and roust least square regression. On the other hand, if the candidate variables exhibit I(1) characteristics, the Johansen cointegration technique, FMOLS, and DOLS technique are commonly used. In the second case, if the integration order of the variables is mixed, the study employed the ARDL-Bounds testing approach that gives sound inferences of parameter estimates of the interest. In this study, the study benefited from the ARDLbounds testing approach for estimating the short- and long-term elasticities of the studied variables. The different cointegration techniques are available to estimate the long-run relationship between the variables of interest. A few of them are listed below:

(i) Engle-Granger two-step cointegration process

(ii) Johanson cointegration, and

(iii) ARDL cointegration procedure.

The first cointegration process use for bivariate analysis linked with the variables' omission bias issue. The second procedure estimates by trace statistics and maximum eigenvalue statistics to establish the cointegration vector in a model. This procedure uses when the variables possess I(1) characteristics. Finally, the ARDL cointegration assesses the long-run relationship between the interested variables. For this purpose, different lag lengths have been checked with different regressors and evaluated the estimates through imposing restrictions through Wald F-statistics. In this study, the ARDL cointegration procedure deal with autocorrelation and heteroskedasticity issues.

For estimating parameters of the interested variables, the following statistical techniques are usually getting insights into the earlier studies, i.e.,

(i) OLS regression techniques for $\mathrm{I}(0)$ variables

(ii) Instrumental variables where known endogeneity problem exists

(iii) Regression techniques for I(1) variables, and

(iv) Regression technique for a mixture of $\mathrm{I}(0)$ and $\mathrm{I}(1)$ series

The study used the ARDL Bounds testing approaches that fall in the fourth category of the above-stated technique. Its estimating procedure is pragmatic and straightforward. Its works under finite data sets. It is calculated based on different lag lengths. It comprehends the speed of adjustment of the variables reaching the equilibrium while estimating the error correction term. This test develops by Pesaran et al. [53]. The Wald F-statistics also discriminate whether the model has a long-term cointegration between the variables or not during the period. The Narayan critical values are used for this purpose to support the following stated hypotheses, i.e.,

$$
\begin{aligned}
& \mathrm{H}_{0}: \Gamma_{1}=\Gamma_{2}=\Gamma_{3}=\Gamma_{4}=\Gamma_{5}=\Gamma_{6}=\Gamma_{7}=\Gamma_{8}=\Gamma_{9}=\Gamma_{10}=0 \\
& \mathrm{H}_{1}: \Gamma_{1} \neq \Gamma_{2} \neq \Gamma_{3} \neq \Gamma_{4} \neq \Gamma_{5} \neq \Gamma_{6} \neq \Gamma_{7} \neq \Gamma_{8} \neq \Gamma_{9} \neq \Gamma_{10} \neq 0
\end{aligned}
$$

Narayan suggested two different critical bound values to decide whether the $\mathrm{H}_{0}$ accepts against the $\mathrm{H}_{1}$ or vice versa. The lower and upper bounds critical values are helpful to determine the decision about the viability of the stated hypotheses to support the cointegration process. Equation (1) is transformed in a schematic style of ARDL Bounds testing procedure, i.e.,

$$
\begin{aligned}
& \Delta \ln (\mathrm{MRR})_{\mathrm{t}}=\Gamma_{0}+\Gamma_{1} \sum_{\mathrm{i}=1}^{\mathrm{p}} \Delta(\mathrm{MRR})_{\mathrm{t}-\mathrm{i}}+\Gamma_{2} \sum_{\mathrm{i}=1}^{\mathrm{q}} \Delta(\mathrm{WA})_{\mathrm{t}-\mathrm{i}}+\Gamma_{3} \sum_{\mathrm{i}=1}^{\mathrm{r}} \Delta(\mathrm{AL})_{\mathrm{t}-\mathrm{i}}+\Gamma_{4} \sum_{\mathrm{i}=1}^{\mathrm{s}} \Delta(\mathrm{WGF})_{\mathrm{t}-\mathrm{i}} \\
& +\Gamma_{5} \sum_{\mathrm{i}=1}^{\mathrm{t}} \Delta(\mathrm{BM})_{\mathrm{t}-\mathrm{i}}+\Gamma_{6} \sum_{\mathrm{i}=1}^{\mathrm{u}} \Delta(\mathrm{WAF})_{\mathrm{t}-\mathrm{i}}+\Gamma_{7} \sum_{\mathrm{i}=1}^{\mathrm{v}} \Delta(\mathrm{CO} 2)_{\mathrm{t}-\mathrm{i}}+\Gamma_{8} \sum_{\mathrm{i}=1}^{\mathrm{W}} \Delta(\mathrm{WPEP})_{\mathrm{t}-\mathrm{i}}+\Gamma_{9} \sum_{\mathrm{i}=1}^{\mathrm{x}} \Delta(\mathrm{CPI})_{\mathrm{t}-\mathrm{i}} \\
& +\Gamma_{10} \sum_{\mathrm{i}=1}^{\mathrm{y}} \Delta(\mathrm{GDPPC})_{\mathrm{t}-\mathrm{i}}+\Gamma_{11} \sum_{\mathrm{i}=1}^{\mathrm{z}} \Delta(\mathrm{WEA})_{\mathrm{t}-\mathrm{i}}+\mathrm{ECT}_{\mathrm{t}-\mathrm{i}}+\Phi_{1}(\mathrm{WA})_{\mathrm{t}-\mathrm{i}}+\Phi_{2}(\mathrm{AL})_{\mathrm{t}-\mathrm{i}}+\Phi_{3}(\mathrm{WGF})_{\mathrm{t}-\mathrm{i}}+\Phi_{4}(\mathrm{BM})_{\mathrm{t}-\mathrm{i}} \\
& +\Phi_{5}(\mathrm{WAF})_{\mathrm{t}-\mathrm{i}}+\Phi_{6}(\mathrm{CO} 2)_{\mathrm{t}-\mathrm{i}}+\Phi_{7}(\mathrm{WPEP})_{\mathrm{t}-\mathrm{i}}+\Phi_{8}(\mathrm{CPI})_{\mathrm{t}-\mathrm{i}}+\Phi_{9}(\mathrm{GDPPC})_{\mathrm{t}-\mathrm{i}}+\Phi_{10}(\mathrm{WEA})_{\mathrm{t}-\mathrm{i}}+\varepsilon_{\mathrm{it}}
\end{aligned}
$$


where $\Delta$ shows the first difference, and ECT shows the error correction term.

The VAR Granger causality test is performed on the studied variables and evaluated the cause-effect relationship between the variables in four different ways, i.e.,

(i) Feedback Causality

(ii) One-way causality

(iii) (xv)Reverse causality, and

(iv) No Causality

The Granger causality estimates check by chi-square statistic values. The bidirectional causality shows co-movement between the variables. The one-way causality is specifically running causality from one variable, like $X$, to another variable, like $Y$. The reverse causality has some other specific determinants, as its moves from variable $Y$ to variable $X$. Finally, there is no causal relationship exists between the candidate variables. However, its impact might have some significant impact on the regression apparatus.

The final step is to assess the relationship between the interested variables in the inter-temporal forecasting procedure. The endogenous variable innovatively shocked by the regressors over the time horizon. Thus, it gives sound policy inferences for resource conservation agenda in a given country context.

\section{Results}

Table 3 shows the descriptive statistics and found that the country has abundant mineral resources contributing to the country's economic growth. The maximum value of mineral resource rent is $19.5050 \%$ of its GDP with an average value of $6.143 \%$ of GDP. On average, the country has a moderate level of women's autonomy as it shows an index value of 33.653. The higher value of ecological destruction and lower women footprints on arable land substantially confirmed the importance of women's autonomy in the resource extractive industry. The average value of the broad money supply is $10.906 \%$ of its GDP, while a significantly lower portion of women's access to the financial market is $0.373 \%$ of GDP. The maximum value of carbon emissions reaches 0.146 metric tons per capita, while women's environmental protection participation is slightly lower to reduce carbon emissions. The average reduction of carbon emissions by involving women in the climate change agenda is 0.003 metric tons per capita. The high GDP deflator tends to show the price level changes, while economic growth and women's economic autonomy increase mineral resource rents in a country. The trend analysis gives the wisdom to understand the characteristics of the variables over a while.

Table 3. Descriptive statistics.

\begin{tabular}{lccccccccccc}
\hline Methods & MRR & WA & AL & WGF & BM & WAF & CO2 & WPEP & CPI & GDPPC & WEA \\
\hline Mean & 6.143 & 33.653 & $6,764,556$ & $242,063.8$ & 10.906 & 0.373 & 0.071 & 0.003 & 896.667 & 539.442 & $16,412.93$ \\
Maximum & 19.505 & 78.800 & $7,100,000$ & $288,744.6$ & 72.372 & 3.132 & 0.146 & 0.006 & $26,765.8$ & 1048.551 & $33,382.85$ \\
Minimum & 0.143 & 23.100 & $6,545,000$ & $199,090.7$ & 2.857 & 0.095 & 0.016 & 0.0004 & 0.993 & 276.055 & 7757.172 \\
Std. Dev. & 5.926 & 13.661 & 170,646 & $33,769.75$ & 10.426 & 0.464 & 0.048 & 0.002 & 4020.32 & 245.612 & 5812.232 \\
Skewness & 0.957 & 1.611 & 1.259 & 0.183 & 4.805 & 4.930 & 0.438 & 0.489 & 6.127 & 0.557 & 0.682 \\
Kurtosis & 2.596 & 5.330 & 3.041 & 1.314 & 28.412 & 29.230 & 1.464 & 1.498 & 39.856 & 1.670 & 3.497 \\
\hline
\end{tabular}

Note: MRR—-mineral resource rents, WA—women's autonomy, AL—arable land, WGF—women green footprints, BM—broad money supply, WAF—-women access to finance, $\mathrm{CO} 2$ - carbon emissions, WPEP—-women participation in environmental protection, WHAwomen household affairs, GDPPC — GDP per capita, WEA—women economic autonomy.

Table 4 shows the ADF unit root estimates and found that mineral resource rents, women's autonomy, arable land, women green ecological footprints, carbon emissions, women participation in environmental protection, GDP per capita, and women's economic autonomy established the non-stationary series with an order of integration is one, i.e., I(1) variables. The remaining variables, i.e., broad money supply and women's access to finance, are stationary at level, thus exhibit I(0) variables. The studied variables have a mixed order of integration. Thus, it needs to use ARDL Bounds cointegration for robust inferences. 
Table 4. ADF unit root estimates.

\begin{tabular}{ccccc}
\hline \multirow{2}{*}{ Variables } & \multicolumn{2}{c}{ Level } & \multicolumn{2}{c}{ First Difference } \\
\cline { 2 - 5 } & Constant & Constant + Trend & Constant & Constant + Trend \\
\hline \multirow{2}{*}{ MRR } & -0.614 & -1.431 & -5.496 & -5.543 \\
& $(0.856)$ & $(0.837)$ & $(0.000)$ & $(0.000)$ \\
\hline \multirow{2}{*}{ WA } & 2.034 & 0.075 & -5.495 & -6.147 \\
& $(0.999)$ & $(0.996)$ & $(0.000)$ & $(0.000)$ \\
\hline \multirow{2}{*}{ AL } & 0.299 & -1.663 & -4.468 & -0.458 \\
& $(0.916)$ & $(0.750)$ & $(0.000)$ & $(0.004)$ \\
\multirow{2}{*}{ WGF } & -1.016 & -1.919 & -6.705 & -6.653 \\
& $(0.739)$ & $(0.627)$ & $(0.000)$ & $(0.000)$ \\
\hline \multirow{2}{*}{ BM } & -6.084 & -6.146 & -1.239 & -1.368 \\
& $(0.000)$ & $(0.000)$ & $(0.645)$ & $(0.852)$ \\
\hline \multirow{2}{*}{ WAF } & -5.712 & -6.428 & -1.434 & -1.547 \\
& $(0.000)$ & $(0.000)$ & $(0.553)$ & $(0.792)$ \\
\hline \multirow{2}{*}{ CO2 } & 1.205 & -1.509 & -7.025 & -7.021 \\
& $(0.664)$ & $(0.814)$ & $(0.000)$ & $(0.000)$ \\
\hline \multirow{2}{*}{ WPEP } & -1.150 & -1.429 & -7.303 & -7.332 \\
& $(0.687)$ & $(0.838)$ & $(0.000)$ & $(0.000)$ \\
\hline \multirow{2}{*}{ WHA } & -6.148 & -6.097 & -11.689 & -11.550 \\
& $(0.000)$ & $(0.000)$ & $(0.000)$ & $(0.000)$ \\
\hline \multirow{2}{*}{ GDPPC } & -1.380 & -0.745 & -3.193 & -3.344 \\
& $(0.583)$ & $(0.962)$ & $(0.027)$ & $(0.072)$ \\
\hline \multirow{2}{*}{ WEA } & 0.623 & 1.732 & -2.227 & -5.211 \\
& $(0.988)$ & $(1.000)$ & $(0.199)$ & $(0.000)$ \\
\hline \multirow{2}{*}{ WO } & & & & \\
\hline
\end{tabular}

Note: Small bracket-probability value. MRR—-mineral resource rents, WA-women's autonomy, AL-arable land, WGF-women green footprints, BM—broad money supply, WAF-women access to finance, $\mathrm{CO}$ - carbon emissions, WPEP-women participation in environmental protection, WHA-women household affairs, GDPPCGDP per capita, WEA-women economic autonomy.

Table 5 shows six different models, i.e., Model-I, Model-III, Model-IV, Model-VII, Model-IX, and Model-XI, that confirmed the long-run cointegration relationship between the stated variables, while the rest of the variables does not tend to show a significant value of Wald F-statistics. Hence it does not exhibit the long-run relationship between the candidate variables. The results confirmed different lag lengths and different trend regressors by stetting maximum second lags of the dependent variable and their regressors. The diagnostic tests only confirmed Model-I and Model-IV that have no normality, autocorrelation, heteroskedasticity, and Ramsey RESET test. The remaining variables partially supported these diagnostic tests to confirm the long-run relationship between the candidate variables.

Table 6 shows the ARDL Bounds testing estimates and found that in the short-run, women's autonomy decreases mineral resource rents, while this result evaporated in the long-run and confirmed the positive relationship between the two variables. The result implies that women empowerment tends to conserve natural resources through water and soil conservation measures [54,55], knowledge spillovers [56], inclusive development [57], and technology advancement [58]. These factors empower women to use natural resources to support their household affairs and promote sustainable development agenda accordingly. Further, in the short- and long-run, ecological footprints jeopardy for mineral resource rents. The number of earlier studies confined their findings in support of the mentioned result; for instance, Aldakhil et al. [1] confirmed that natural resource conservation agenda is negatively affected by ecological footprints, high population density, and using conventional non-renewable energy consumption, while it can improve through increasing technological cooperation grants across countries. Yue et al. [59] argued that ecological footprints further pressure the global environment to pollute air quality levels. Nassani et al. [60] stressed 
the need to impose material pricing to conserve the natural resource efficiency agenda for broad-based growth.

Financial development played a crucial role in establishing the commodity resource market. In the short- and long-run, broad money supply negatively affects mineral resource rents, while empowering women through easy access to finance helps them support the mineral resource market to improve resource rents. Khan et al. [61] confirmed that financial development hurts the resource commodity market that required stringent government regulations to control commodity prices. Dogan et al. [62] found a positive impact of natural resource rents on financial development. Khan et al. [63] argued that financial development, population density, and carbon pricing decreases coal, mineral, and oil rents. The inclusive growth policies would help reduce the negative externality on the resource market through sound financial planning. Sinha and Sengupta [64] confirmed the direct relationship between human development and natural resource rents under globalization and governance factors. Asif et al. [65] concluded that the optimal way to use natural resources helps support financial activities and economic growth. Baum and BenshaulTolonen [66] emphasized the role of gender equality in extractive resource industries and argued that women suppressed in all forms in the resource extractive industries that sabotaged the inclusive global growth agenda. Ibrahim et al. [67] concluded that women in artisanal mining suffered from fundamental women's rights to work in the mining sector, which further led to a lack of accessibility to the financial market. The state intervention is needed to culminate gender inequality in all forms to go-for inclusive development.

A direct relationship exhibits between carbon emissions and mineral resource rents both in the short- and long-term. The result implies that the natural resource market link with carbon emissions. Further, women's environmental protection participation positively impacted the mineral resource market to increase its rent relative to the country's GDP. Shafiei and Maleksaeidi [68] confirmed the study's stated findings and concluded that females are more environmentally friendly than males. Xie et al. [69] concluded that women as corporative board members are always keen to propose environmentally friendly policies to go-for carbon mitigating strategies. Islam and Managi [70] stressed the need to spread environmental knowledge to improve pro-environmental behavior in the commodity resource market worldwide.

The price level changes continued economic growth, and women's economic autonomy substantially increases mineral resource rents in the short-run. In contrast, in the long-run, women's economic autonomy is disappeared and shows an indirect relationship with mineral resource rents. The result implies that women's economic autonomy is the center of a debate that positively impacts the resource market in the short-term, which further needs to transmit its positive impact in the long-term. For the positive impact of women's economic autonomy, it is imperative to empower women in pollitical decisions and corporate level decisions to equip them with the latest technology and training skills to acquire knowledge to conserve natural resource agenda in a country. Yasmin and Grundmann [71] confirmed that the stated research findings argued that women empowerment in the decision-making process is crucial for using renewable fuel. Purnamawati and Adnyani [72] argued that human resource quality improvement helps empower women to use natural resources and strengthen the regional economy through technological advancement. Asi and Williams [58] emphasized gender equality through healthcare information technology that supports women for easy accessibility of the healthcare system. Montanari and Bergh [73] stressed the need to use women's traditional knowledge in natural resource product development and included them in the resource policymaking system to empower them to conserve natural resources. 
Table 5. Results of the ARDL cointegration test.

\begin{tabular}{|c|c|c|c|c|c|c|c|}
\hline \multirow{2}{*}{ Models } & \multirow{2}{*}{ Models } & \multirow{2}{*}{ ARDL Lag Length } & \multirow{2}{*}{ Wald F-Statistics } & \multicolumn{4}{|c|}{$\begin{array}{l}\text { Diagnostic Tests } \\
\end{array}$} \\
\hline & & & & JB Normality Test & Heteroskedasticity & LM Serial Correlation & Ramsey RESET \\
\hline Model-I & $\begin{array}{l}\text { MRR/WA, AL, WGF, } \\
\text { BM, WAF, CO2, WPEP, } \\
\text { CPI, GDPPC, WEA }\end{array}$ & $2,2,2,2,2,2,2,2,2,2,2$ & $3.949 * *$ & $\begin{array}{c}1.253 \\
(0.534)\end{array}$ & $\begin{array}{c}0.990 \\
(0.543)\end{array}$ & $\begin{array}{c}1.292 \\
(0.296)\end{array}$ & $\begin{array}{l}1.158 \\
(0.276)\end{array}$ \\
\hline Model-II & $\begin{array}{l}\text { WA/MRR, AL, WGF, } \\
\text { BM, WAF, CO2, WPEP, } \\
\text { CPI, GDPPC, WEA }\end{array}$ & $2,2,2,0,0,0,0,0,0,2,2$ & 2.767 & $\begin{array}{l}10.019 \\
(0.000)\end{array}$ & $\begin{array}{c}1.131 \\
(0.387)\end{array}$ & $\begin{array}{c}7.368 \\
(0.004)\end{array}$ & $\begin{array}{c}2.139 \\
(0.044)\end{array}$ \\
\hline Model-III & $\begin{array}{l}\text { AL/WA, MRR, WGF, } \\
\text { BM, WAF, CO2, WPEP, } \\
\text { CPI, GDPPC, WEA }\end{array}$ & $1,0,0,2,1,1,2,2,2,0,0$ & $3.088^{* * *}$ & $\begin{array}{c}9.031 \\
(0.010)\end{array}$ & $\begin{array}{c}0.721 \\
(0.776)\end{array}$ & $\begin{array}{c}4.890 \\
(0.028)\end{array}$ & $\begin{array}{c}2.412 \\
(0.031)\end{array}$ \\
\hline Model-V & $\begin{array}{l}\text { BM/WA, AL, WGF, } \\
\text { MRR, WAF, CO2, WPEP, } \\
\text { CPI, GDPPC, WEA }\end{array}$ & $2,2,0,2,02,2,2,0,2,2$ & 1.661 & $\begin{array}{c}0.559 \\
(0.755)\end{array}$ & $\begin{array}{c}1.211 \\
(0.356)\end{array}$ & $\begin{array}{c}9.692 \\
(0.002)\end{array}$ & $\begin{array}{c}1.839 \\
(0.087)\end{array}$ \\
\hline Model-VI & $\begin{array}{c}\text { WAF/WA, AL, WGF, } \\
\text { BM, MRR, CO2, WPEP, } \\
\text { CPI, GDPPC, WEA }\end{array}$ & $2,2,2,0,2,0,2,2,0,2,2$ & 1.668 & $\begin{array}{c}0.555 \\
(0.757)\end{array}$ & $\begin{array}{c}1.221 \\
(0.349)\end{array}$ & $\begin{array}{c}9.724 \\
(0.002)\end{array}$ & $\begin{array}{c}2.522 \\
(0.024)\end{array}$ \\
\hline Model-VII & $\begin{array}{l}\mathrm{CO} 2 / \mathrm{WA}, \mathrm{AL}, \mathrm{WGF}, \\
\text { BM, WAF, MRR, WPEP, } \\
\text { CPI, GDPPC, WEA }\end{array}$ & $2,2,1,1,2,1,2,2,1,1,1$ & $5.055^{*}$ & $\begin{array}{c}3.148 \\
(0.207)\end{array}$ & $\begin{array}{c}0.343 \\
(0.992)\end{array}$ & $\begin{array}{l}1.122 \\
(0.355)\end{array}$ & $\begin{array}{r}5.295 \\
(0.000)\end{array}$ \\
\hline Model-VIII & $\begin{array}{l}\text { WPEP/WA, AL, WGF, } \\
\text { BM, WAF, CO2, MRR, } \\
\text { CPI, GDPPC, WEA }\end{array}$ & $2,2,1,2,1,2,1,2,1,1,1$ & 3.010 & $\begin{array}{c}1.079 \\
(0.582)\end{array}$ & $\begin{array}{c}0.430 \\
(0.927)\end{array}$ & $\begin{array}{c}0.574 \\
(0.576)\end{array}$ & $\begin{array}{c}8.182 \\
(0.000)\end{array}$ \\
\hline Model-IX & $\begin{array}{l}\text { CPI/WA, AL, WGF, BM, } \\
\text { WAF, CO2, WPEP, MRR, } \\
\text { GDPPC, WEA }\end{array}$ & $2,1,2,2,1,2,2,1,2,0,1$ & $12.561^{*}$ & $\begin{array}{c}0.893 \\
(0.639)\end{array}$ & $\begin{array}{c}0.821 \\
(0.681)\end{array}$ & $\begin{array}{c}3.582 \\
(0.057)\end{array}$ & $\begin{array}{l}16.579 \\
(0.000)\end{array}$ \\
\hline Model-X & $\begin{array}{l}\text { GDPPC/WA, AL, WGF, } \\
\text { BM, WAF, CO2, WPEP, } \\
\text { CPI, GMRR, WEA }\end{array}$ & $1,0,2,2,1,1,2,0,2,2,2$ & 2.558 & $\begin{array}{c}2.614 \\
(0.270)\end{array}$ & $\begin{array}{c}1.574 \\
(0.173)\end{array}$ & $\begin{array}{c}7.007 \\
(0.005)\end{array}$ & $\begin{array}{c}0.369 \\
(0.717)\end{array}$ \\
\hline Model-XI & $\begin{array}{l}\text { WEA/WA, AL, WGF, } \\
\text { BM, WAF, CO2, WPEP, } \\
\text { CPI, GDPPC, MRR }\end{array}$ & $2,2,0,0,0,0,0,0,2,2,2$ & $3.467^{* *}$ & $\begin{array}{c}0.626 \\
(0.730)\end{array}$ & $\begin{array}{c}1.578 \\
(0.151)\end{array}$ & $\begin{array}{c}7.001 \\
(0.005)\end{array}$ & $\begin{array}{c}3.099 \\
(0.005)\end{array}$ \\
\hline \multirow{4}{*}{ Narayan Critical Values } & Level of Significance & Lowe & & Upp & s I(1) & \multirow{4}{*}{\multicolumn{2}{|c|}{$\begin{array}{c}\text { Note: ***, and }{ }^{* * *} \text { shows } 1 \%, 5 \% \text {, and } 10 \% \\
\text { level of significance. }\end{array}$}} \\
\hline & $10 \%$ & \multicolumn{2}{|c|}{$\begin{array}{l}2.07 \\
2.33\end{array}$} & \multicolumn{2}{|c|}{3.16} & & \\
\hline & $5 \%$ & & & \multicolumn{2}{|c|}{3.46} & & \\
\hline & $1 \%$ & \multicolumn{2}{|c|}{2.84} & \multicolumn{2}{|c|}{4.10} & & \\
\hline
\end{tabular}

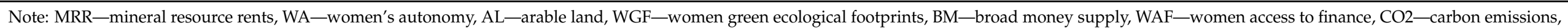

WPEP — women participation in environmental protection, CPI—inflation, GDPPC—GDP per capita, WEA —women's economic autonomy. 
Table 6. ARDL-bounds testing estimates.

\begin{tabular}{|c|c|c|c|}
\hline Variables & ARDL-I & ARDL-II & ARDL-III \\
\hline$\Delta \ln (\mathrm{WA})_{\mathrm{t}}$ & 0.125 & $-7.163 *$ & 1.580 \\
\hline$\Delta \ln (\mathrm{WA})_{\mathrm{t}-1}$ & -1.153 & - & $-7.478 *$ \\
\hline$\Delta \ln (\mathrm{WA})_{\mathrm{t}-2}$ & -2.051 & - & - \\
\hline$\Delta \ln (\mathrm{AL})_{\mathrm{t}}$ & 13.181 & - & 18.564 \\
\hline$\Delta \ln (\mathrm{AL})_{\mathrm{t}-1}$ & 23.435 & - & - \\
\hline$\Delta \ln (\mathrm{WGF})_{\mathrm{t}}$ & - & $-3.860 * * *$ & $-7.560 * *$ \\
\hline$\Delta \ln (\mathrm{BM})_{\mathrm{t}}$ & -0.206 & - & $-2.570 * *$ \\
\hline$\Delta \ln (\mathrm{BM})_{\mathrm{t}-1}$ & -0.008 & - & - \\
\hline$\Delta \ln (\mathrm{BM})_{\mathrm{t}-2}$ & $0.338 * *$ & - & - \\
\hline$\Delta \ln (\mathrm{WAF})_{\mathrm{t}}$ & - & -0.116 & $2.522 * *$ \\
\hline$\Delta \ln (\mathrm{WAF})_{\mathrm{t}-1}$ & - & -0.090 & - \\
\hline$\Delta \ln (\mathrm{WAF})_{\mathrm{t}-2}$ & - & $0.420 *$ & - \\
\hline$\Delta \ln (\mathrm{CO} 2)_{\mathrm{t}}$ & $1.627 *$ & - & -0.375 \\
\hline$\Delta \ln (\mathrm{CO} 2)_{\mathrm{t}-1}$ & $-0.882 * * *$ & - & - \\
\hline$\Delta \ln (\mathrm{WPEP})_{\mathrm{t}}$ & - & $0.722 * * *$ & $454.173^{\mathrm{a}, * *}$ \\
\hline$\Delta \ln (\mathrm{WPEP})_{\mathrm{t}-1}$ & - & -0.357 & - \\
\hline$\Delta \ln (\mathrm{WPEP})_{\mathrm{t}-2}$ & - & -0.657 & - \\
\hline$\Delta \ln (\mathrm{CPI})_{\mathrm{t}}$ & $0.155^{*}$ & - & - \\
\hline$\Delta \ln (\mathrm{GDPPC})_{\mathrm{t}}$ & 8.694 * & - & $6.336^{* *}$ \\
\hline$\Delta \ln (\mathrm{GDPPC})_{\mathrm{t}-1}$ & - & - & $-8.722 *$ \\
\hline$\Delta \ln (\mathrm{WEA})_{\mathrm{t}}$ & - & $8.011 *$ & -0.000016 \\
\hline$\Delta \ln (\text { WEA })_{t-1}$ & - & -1.383 & $0.00034^{*}$ \\
\hline $\mathrm{ECT}_{\mathrm{t}-1}$ & $-1.106^{*}$ & -0.460 * & $-1.086^{*}$ \\
\hline \multicolumn{4}{|c|}{ Long-run Elasticity Estimates } \\
\hline $\ln (\mathrm{WA})$ & $3.268 *$ & 5.979 & $9.354 *$ \\
\hline $\ln (\mathrm{AL})$ & $-16.772^{* * *}$ & - & -4.940 \\
\hline $\ln (\mathrm{WGF})$ & - & $-8.383^{* * *}$ & $-6.959 * *$ \\
\hline $\ln (\mathrm{BM})$ & $-0.771^{* *}$ & - & $-2.365^{* *}$ \\
\hline $\ln (\mathrm{WAF})$ & - & -1.190 & $2.167^{* * *}$ \\
\hline $\ln (\mathrm{CO} 2)$ & $2.267 *$ & - & 0.462 \\
\hline $\ln (\mathrm{WPEP})$ & - & $3.849^{* *}$ & $418.055^{\mathrm{a}, * *}$ \\
\hline $\ln (\mathrm{CPI})$ & $0.140^{* *}$ & - & - \\
\hline $\ln (\mathrm{GDPPC})$ & $2.394^{*}$ & - & $9.733 *$ \\
\hline $\ln (\mathrm{WEA})$ & - & 0.514 & $-0.0004^{*}$ \\
\hline Constant & 243.235 & - & 84.348 \\
\hline \multicolumn{4}{|l|}{ Diagnostic Tests } \\
\hline Wald F-statistics & $3.654^{* * *}$ & $4.001^{* * *}$ & $4.359 *$ \\
\hline JB Test & 0.513 & 0.310 & $0.656^{\mathrm{b}}$ \\
\hline LM Test & 0.667 & 0.170 & $0.649^{b}$ \\
\hline Heteroskedasticity Test & 1.196 & 0.359 & $0.628^{b}$ \\
\hline Ramsey RESET Test & 0.570 & $1.930^{* * *}$ & $1.336^{\mathrm{b}}$ \\
\hline
\end{tabular}

Note: a estimates without natural logarithm, ${ }^{\mathrm{b}}$ estimates at level. ${ }^{*} p<0.000,{ }^{* *} p<0.050,{ }^{* * *} p<0.090$. MRR—mineral resource rents, WA—women's autonomy, AL—arable land, WGF-women green footprints, BM-broad money supply, WAF-women access to finance, $\mathrm{CO} 2$ - carbon emissions, WPEP — women participation in environmental protection, WHA—women household affairs, GDPPC—GDP per capita, WEA—women economic autonomy. 


\section{Discussion}

Figure 1 shows the estimates of VAR Granger causality for ready reference.

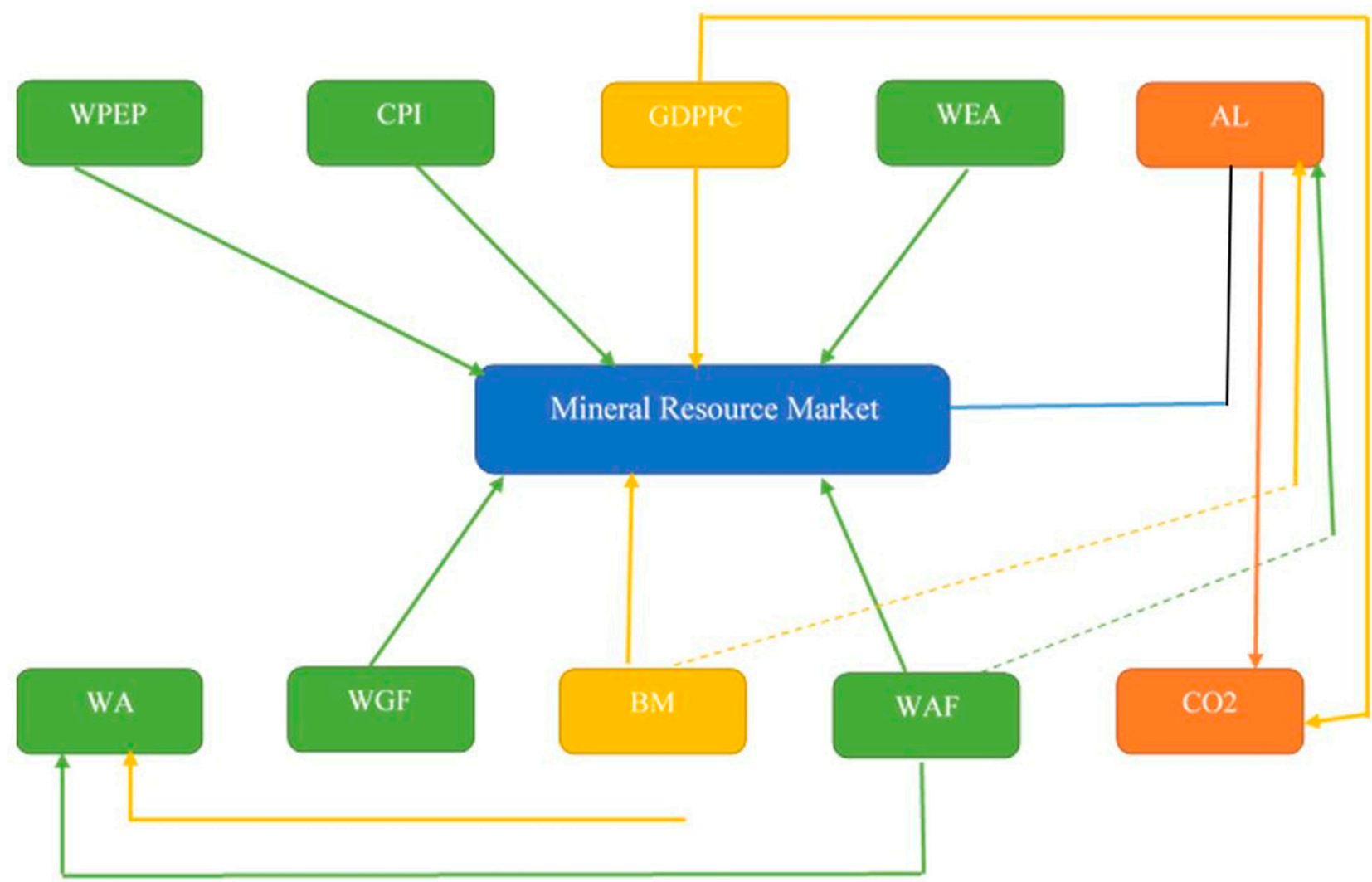

Figure 1. VAR Granger causality estimates. Source: authors estimation. Note: WA-women's autonomy, AL—arable land, WGF-women's green footprints, BM-broad money supply, WAF—women's access to finance, CO2—carbon emissions, WPEP—women's participation in environmental protection, WHA—-women's household affairs, GDPPC—GDP per capita, WEA-women's economic autonomy.

The causality estimates confirmed that women's autonomy factors, including women's participation in environmental protection, women's economic autonomy, women's access to finance, and green ecological footprints Granger cause mineral resource rents. The result implies that women's autonomy factors linked it with the commodity market to increase resource rents. Few other factors Granger cause mineral resource rents, including changes in the price level, GDP per capita, broad money supply, and carbon emissions. These factors cause mineral resource rents in a country. GDP per capita Granger causes carbon emissions to confirm growth led emissions hypothesis, whereas inflation Granger cause women green ecological footprints established the substantial causation between the two factors. The one-way causation running from (i) broad money supply to women's autonomy to support finance-led women's autonomy hypothesis, (ii) women's access to finance to women's autonomy to establish the importance of finance in women's empowerment, (iii) women's autonomy to women's ecological footprints, (iv) mineral resource rents to arable land, and (v) broad money supply and women access to finance to ecological footprints. The causality estimates would propose sound policy implications for women's empowerment in the country's mining sector. Table 7 shows the VDA estimates of mineral resource rents for ready reference. 
Table 7. Variance decomposition estimates of MRR.

\begin{tabular}{|c|c|c|c|c|c|c|c|c|c|c|c|c|}
\hline Period & S.E. & MRR & WA & AL & WGF & BM & WAF & $\mathrm{CO} 2$ & WPEP & CPI & GDPPC & WEA \\
\hline 2021 & 2.283 & 74.559 & 4.152 & 0.280 & 1.996 & 0.339 & 2.769 & 1.017 & 2.430 & 4.215 & 0.754 & 7.4843 \\
\hline 2022 & 2.616 & 56.948 & 4.042 & 1.494 & 1.610 & 0.655 & 8.045 & 2.418 & 3.313 & 3.967 & 4.152 & 13.352 \\
\hline 2023 & 3.173 & 40.098 & 5.131 & 1.277 & 1.299 & 0.628 & 19.617 & 1.669 & 2.782 & 2.808 & 6.311 & 18.374 \\
\hline 2024 & 3.497 & 33.070 & 6.601 & 1.199 & 1.459 & 1.264 & 21.301 & 1.830 & 2.747 & 2.704 & 6.555 & 21.265 \\
\hline 2025 & 3.819 & 28.771 & 6.416 & 1.989 & 1.465 & 2.751 & 19.277 & 2.593 & 2.457 & 3.358 & 5.696 & 25.222 \\
\hline 2026 & 4.101 & 26.031 & 5.768 & 2.780 & 1.957 & 3.526 & 17.568 & 2.319 & 2.224 & 3.315 & 4.941 & 29.565 \\
\hline 2027 & 4.411 & 23.091 & 5.078 & 3.523 & 2.306 & 3.752 & 16.765 & 2.032 & 1.922 & 2.890 & 4.320 & 34.315 \\
\hline 2028 & 4.716 & 20.575 & 4.449 & 4.690 & 2.651 & 3.892 & 16.785 & 1.797 & 1.742 & 2.536 & 3.962 & 36.915 \\
\hline 2029 & 5.017 & 19.076 & 4.057 & 7.058 & 2.467 & 3.671 & 15.861 & 1.781 & 1.703 & 2.247 & 4.006 & 38.066 \\
\hline
\end{tabular}

Note: MRR—-mineral resource rents, WA—women's autonomy, AL—arable land, WGF—women green footprints, BM-broad money supply, WAF-women access to finance, $\mathrm{CO} 2$ - carbon emissions, WPEP-women participation in environmental protection, WHAwomen household affairs, GDPPC—GDP per capita, WEA—-women economic autonomy.

The results suggested that women's economic autonomy and women's access to finance will play an essential role in determining mineral resource rents over time. The standard variance shocks of both the autonomy factors on mineral resource rents are $38.066 \%$ and $15.861 \%$, respectively. The arable land, the country's per capita income, and women's autonomy subsequently influenced the country's mineral resource rents with a standard variance error shock to 7.058, 4.057, and 4.006, respectively. Broad money supply, women's green footprints, and CPI will significantly impact mineral resource rents with a variance standard error shock of $3.671 \%, 2.467 \%$, and $2.247 \%$, respectively. Figure 2 shows the VDA estimates of socio-economic and environmental factors in a country for ready reference.

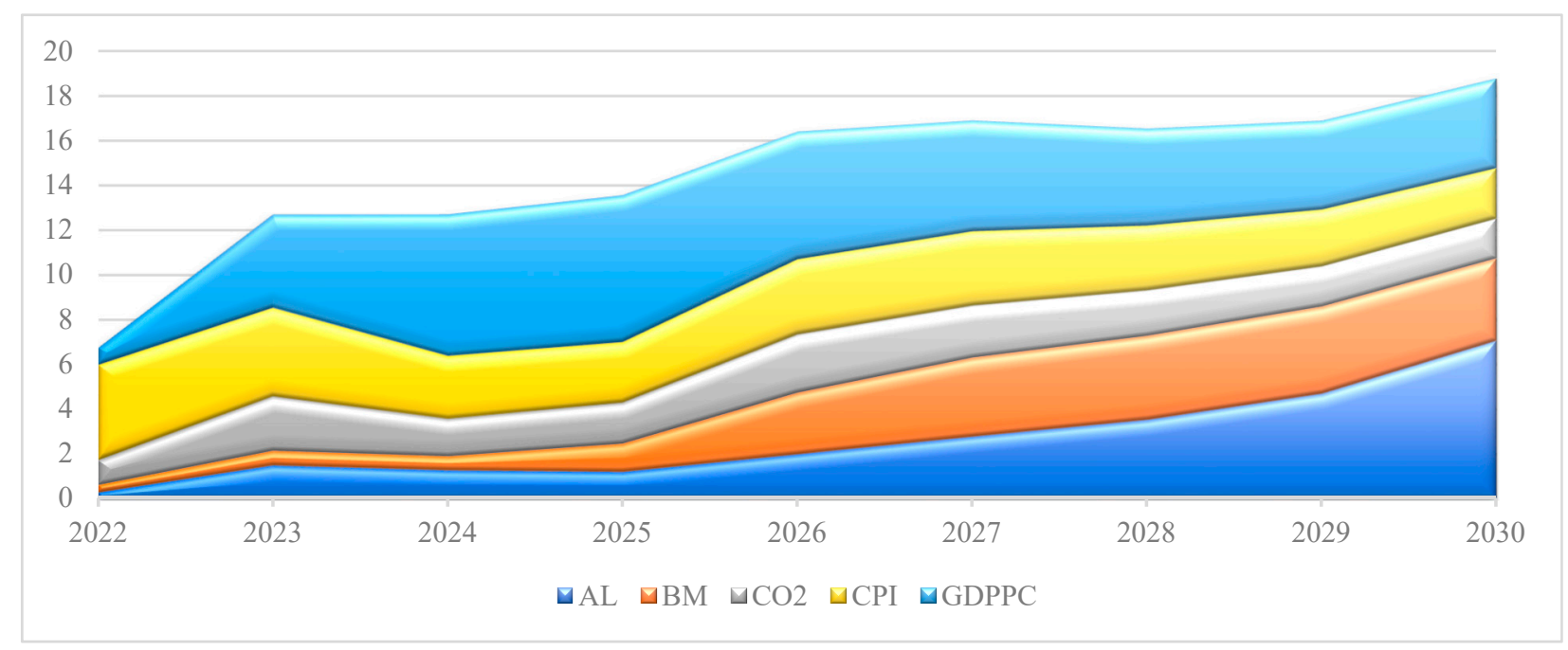

Figure 2. VDA estimates of socio-economic factors in the resource market. Source: authors estimation. Note: AL—arable land, BM—broad money supply, CO2—carbon emissions, CPI—consumer price index, GDPPC—GDP per capita.

The least influenced will be carbon emissions and women's participation in environmental protection on mineral resource rents for the next ten years. The forecasting estimates assure that women's autonomy in the mining sector would improve their inclusive growth agenda. Figure 3 shows the VDA estimates of women's autonomy factors in relationship of mineral resource rents for ready reference.

The least influenced will be carbon emissions and women's participation in environmental protection on mineral resource rents for the next ten years. The forecasting estimates assure that women's autonomy in the mining sector would improve their inclusive growth agenda. The need for regional governance may be helpful to mobilize resource funds and economic harmonization [74], which further support to minimize the COVID-19 cases 
through adaptation plans [75]. Women's roles in decision making processes remains helpful to promote sound economic development [76], hence it is important to get a women voice in parliament for protecting their basic and corporate rights for sustained living [77].

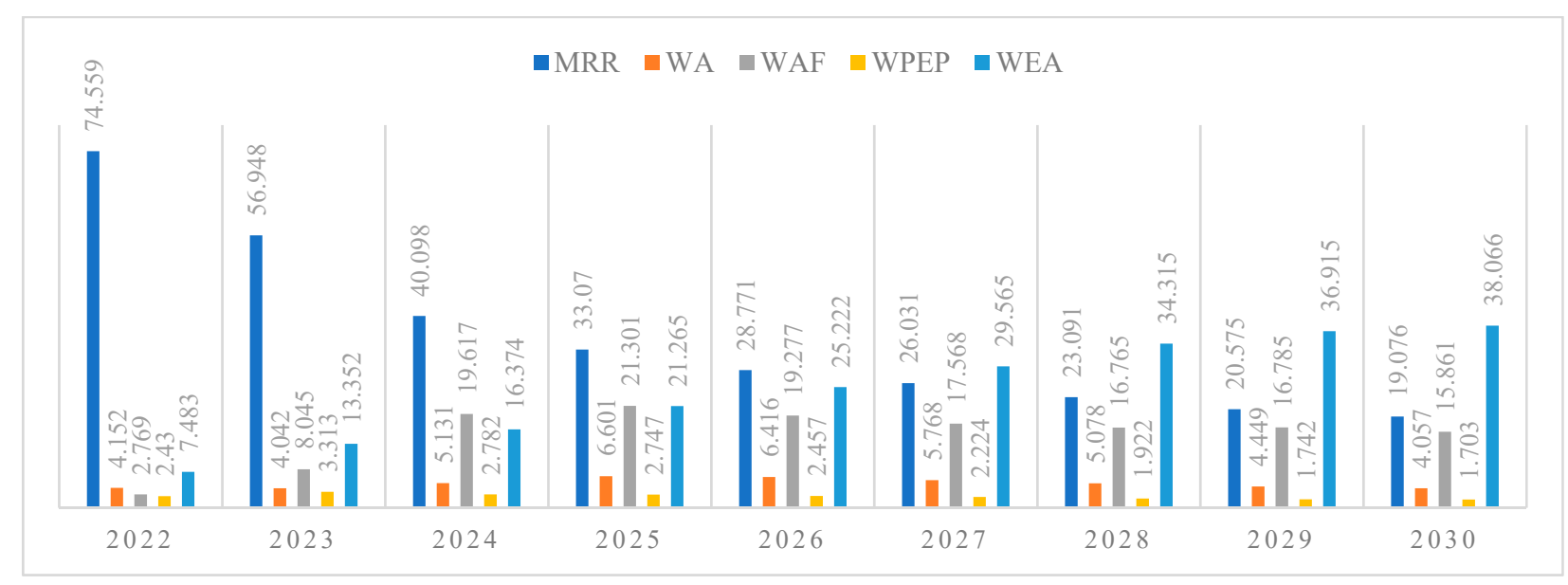

Figure 3. VDA estimates of women's autonomy factors in resource market. Source: authors estimation. Note: MRRmineral resource rents, WA—women's autonomy, WAF-women access to finance, WPEP-women's participation in environmental protection, WEA—women's economic autonomy.

\section{Conclusions}

Women's discrimination in different forms is seen in many parts of the globe. Africa, where women's rights are compromised, is no exception. In particular, the Congolese women faced many unprecedented challenges related to different forms of discrimination, including gender-based violence, high maternal mortality rates, women poverty, sexual violence, rape, and out-of-school children, especially girls, and lack of economic and political opportunities. All these forms of discrimination have put Congolese women more in stress, which may not enable them to participate in labor market outcomes equally. The study aims to assess Congo African women's role in the mining sector by controlling the number of socio-economic and environmental factors. The results show that women's autonomy, women's access to finance, and women's participation in environmental protection are the primary sources that positively affect mineral resource rents. On the other hand, ecological footprints and financial development negatively affect the resource conservation agenda in a country. The causal inferences confirmed the one-way linkages from different women's freedom indicators to mineral resource rents in a given period. The VDA estimates suggest that women's economic autonomy and access to finance will be the main structural factors that will largely influence mineral resource rents for the next ten years.

Without empowering women, the resource sustainability agenda could not be reachable, as stressed by the United Nations sustainable development goal to achieve it by 2030 . In the mining sector, women faced numerous unprecedented challenges, not limited to abuse, accidents, low wage issues, healthcare issues, lack of social support, and absence of fundamental women rights. Weaker institutional quality creates more internal conflicts and civil wars in a country. All these challenges lead them to vulnerable conditions. There is a high need to empower women by allowing participation in the mining sector's decision-making processes, allowing access to artisanal mining activities, providing healthy working conditions, improving their wages compared to their men, and resolving their healthcare issues.

Ecological footprints are considered the negative environmental externalities that cause excessive human demand for natural capital. The continued economic growth puts pressure on resource consumption and waste generation while exploiting the natural environment through unsustainable production. Women leave less ecological footprints 
than men due to their natural loving, environmentally friendly care behavior. Thus, empowering women in the mining sector should be protected by strong legislation and a national integrated agenda that gives them the power of political decisions to improve the natural environment through a sustainable resource conservation program.

Another big problem that faced Congolese women is a financial exclusion in the economic agenda, as women are less likely to get formal financial services and assistance in microfinancing that does not enable them to support their families. The policies to empower women to be included in the financial developmental agenda promotes gender equality while leading to increased societal well-being. The mining women advance toward an inclusive growth agenda, as they have a natural aptitude towards saving and spending a more significant share of their income on children's nutrition, family health, and education compared to men. Thus, it is imperative to promote women's autonomy in the mining sector to get advanced financial loans and assistance so that they can feel safe and secure, ultimately helping them contribute to commodity resource markets to restore extractive industries.

Climate changes are the main obstacle to a country's sustained long-term economic growth. Its negative healthcare disproportionally impacts more women than men. Mining women are exposed mainly to the contamination that leads to many epidemiological diseases. The greater need to protect artisanal mining women through mitigating and recovery strategies is desirable for their healthcare reforms. The unlocking of women's potential in the resource market may enable them to participate in environmental protection strategies, which may protect the country's resource capital.

Women's socio-economic autonomy is not confined to their household affairs, while it leads to resource conservation agendas that help attain the country's vision to achieve the United Nations sustainable development goals.

Author Contributions: Conceptualization, Y.L. and M.K.A., methodology, Y.L., M.K.A. and K.Z.; software, Y.L., M.K.A. and K.Z.; validation, K.Z.; formal analysis, Y.L., M.K.A. and K.Z.; investigation, Y.L. and K.Z.; resources, M.K.A.; data curation, K.Z.; writing-original draft preparation, Y.L., M.K.A. and K.Z.; writing-review and editing, Y.L., M.K.A. and K.Z.; visualization, M.K.A.; supervision, Y.L. and M.K.A.; project administration, Y.L. and M.K.A.; funding acquisition, Y.L. All authors have read and agreed to the published version of the manuscript.

Funding: This work is supported by the National Social Science Fund of China under grant [20CJY057], China Postdoctoral Science Foundation under grant [2020M670617], Scientific Research Project of China (Xi'an) Institute for Silk Road Research under grant [2019ZD01], the Second Batch of "San-Qin Scholars" Post-specific Funding by Shaanxi Province.

Institutional Review Board Statement: Not applicable.

Informed Consent Statement: Not applicable.

Data Availability Statement: The data is freely available at World Development Indicators published by World Bank (2020) at https: / / databank.worldbank.org/source/world-development-indicators (accessed on 12 September 2020).

Conflicts of Interest: The authors declare no conflict of interest.

\section{References}

1. Aldakhil, A.M.; Nassani, A.A.; Zaman, K. The role of technical cooperation grants in mineral resource extraction: Evidence from a panel of 12 abundant resource economies. Resour Policy 2020, 69, 101822. [CrossRef]

2. Kaggwa, M. Interventions to promote gender equality in the mining sector of South Africa. Extr. Ind. Soc. 2020, 7 , 398-404. [CrossRef]

3. Benjamin, E.O.; Ola, O.; Buchenrieder, G. Does an agroforestry scheme with payment for ecosystem services (PES) economically empower women in sub-Saharan Africa? Ecosyst. Serv. 2018, 31, 1-11. [CrossRef]

4. Mangaroo-Pillay, S.; Botha, D. An exploration of women's workplace experiences in the South African mining industry. J. South. Afr. Inst. Min. Metall. 2020, 120, 475-483. [CrossRef]

5. United Nations. Fast Facts: Statistics on Violence Against Women and Girls, UN Women. 2010. Available online: https:/ /www. endvawnow.org/en/articles/299-fast-facts-statistics-on-violence-against-women-and-girls-.html (accessed on 20 December 2020). 
6. World Bank. WASH Poor in a Water-Rich Country. In A Diagnostic of Water, Sanitation, Hygiene, and Poverty in the Democratic Republic of Congo: Executive Summary; The World Bank: Washington, DC, USA, 2017.

7. Lugova, H.; Samad, N.; Haque, M. Sexual and Gender-Based Violence Among Refugees and Internally Displaced Persons in the Democratic Republic of the Congo: Post-Conflict Scenario. Risk Manag. Healthc. Policy 2020, 13, 2937. [CrossRef] [PubMed]

8. Nachega, J.B.; Mbala-Kingebeni, P.; Otshudiema, J.; Mobula, L.M.; Preiser, W.; Kallay, O.; Ahuka-Mundeke, S. Responding to the challenge of the dual COVID-19 and Ebola epidemics in the Democratic Republic of Congo-Priorities for achieving control. Am. J. Trop. Med. Hyg. 2020, 103, 597-602. [CrossRef]

9. Roseboom, T.J. Why achieving gender equality is of fundamental importance to improve the health and well-being of future generations: A DOHaD perspective. J. Dev. Orig. Health Dis. 2020, 11, 101-104. [CrossRef]

10. Khosla, R.; Banerjee, J.; Chou, D.; Say, L.; Fried, S.T. Gender equality and human rights approaches to female genital mutilation: A review of international human rights norms and standards. Reprod. Health 2017, 14, 59. [CrossRef]

11. United Nations. Goal 5: Achieve Gender Equality and Empower All Women and Girls. 2015. Available online: https://www.un. org/sustainabledevelopment/gender-equality/ (accessed on 20 December 2020).

12. Botha, D. Barriers to career advancement of women in mining: A qualitative analysis. S. Afr. J. Empl. Relat. 2017, 41, 15-32. [CrossRef]

13. Pactwa, K. Is There a Place for Women in the Polish Mines?-Selected Issues in the Context of Sustainable Development. Sustainability 2019, 11, 2511. [CrossRef]

14. Mugo, D.; Ondieki-Mwaura, F.; Omolo, M. The Social-Cultural Context of Women Participation In Artisanal And Small-Scale Mining: Case Of Taita Taveta Region Of Kenya. Afr. J. Emerg. Issues 2020, 2, 21-30.

15. Bashwira, M.R.; van der Haar, G. Necessity or choice: Women's migration to artisanal mining regions in eastern DRC. Can. J. Afr. Stud. 2020, 54, 79-99. [CrossRef]

16. Orleans-Boham, H.; Sakyi-Addo, G.B.; Tahiru, A.; Amankwah, R.K. Women in artisanal mining: Reflections on the impacts of a ban on operations in Ghana. Extr. Ind. Soc. 2020, 7, 583-586. [CrossRef]

17. Reichel, V. Financial inclusion for women and men in artisanal gold mining communities: A case study from the Democratic Republic of the Congo. Extr. Ind. Soc. 2020, 7, 412-419. [CrossRef]

18. Thankian, K. Factors Affecting Women's Autonomy in Household Decision-Making among Married Women in Zambia. J. Sci Res. Rep. 2020, 26, 109-123. [CrossRef]

19. Pandey, V.; Singh, S.; Unni, J. Markets and Spillover Effects of Political Institutions in Promoting Women's Empowerment: Evidence from India. Fem. Econ. 2020, 26, 1-30. [CrossRef]

20. Holland, C.; Rammohan, A. Rural women's empowerment and children's food and nutrition security in Bangladesh. World Dev. 2019, 124, 104648. [CrossRef]

21. Khan, M.S. Women's entrepreneurship and social capital: Exploring the link between the domestic sphere and the marketplace in Pakistan. Strateg. Chang. 2020, 29, 375-387. [CrossRef]

22. Moreira, J.; Marques, C.S.; Braga, A.; Ratten, V. A systematic review of women's entrepreneurship and internationalization literature. Thunderbird Int. Bus. Rev. 2019, 61, 635-648. [CrossRef]

23. Du, Y.; Ravenscroft, N.; Wang, Y.; Liu, P. Governance, gender and the appropriation of natural resources: A case study of 'left-behind'women's collective action in China. Soc. Nat. Resour. 2019, 32, 382-399. [CrossRef]

24. Ramstetter, L.; Habersack, F. Do women make a difference? Analysing environmental attitudes and actions of Members of the European Parliament. Environ. Politics 2020, 29, 1063-1084. [CrossRef]

25. Birindelli, G.; Iannuzzi, A.P.; Savioli, M. The impact of women leaders on environmental performance: Evidence on gender diversity in banks. Corp. Soc. Responsib. Environ. Manag. 2019, 26, 1485-1499. [CrossRef]

26. DiRienzo, C.E.; Das, J. Women in government, environment, and corruption. Environ. Dev. 2019, 30, 103-113. [CrossRef]

27. Lv, Z.; Deng, C. Does women's political empowerment matter for improving the environment? A heterogeneous dynamic panel analysis. Sustain. Dev. 2019, 27, 603-612. [CrossRef]

28. Allen, E.; Lyons, H.; Stephens, J.C. Women's leadership in renewable transformation, energy justice and energy democracy: Redistributing power. Energy Res. Soc. Sci. 2019, 57, 101233. [CrossRef]

29. Pan, C.; Guo, H.; Jiang, Y.; Wang, H.; Qi, W. The double effects of female executives' participation on corporate sustainable competitive advantage through unethical environmental behavior and proactive environmental strategy. Bus. Strateg. Environ. 2020, 29, 2324-2337. [CrossRef]

30. Zhou, Y.; Sun, X. Toward gender sensitivity: Women and climate change policies in China. Int. Fem. J. Politics 2020, 22, 127-149. [CrossRef]

31. Benya, A.P. Women in Mining: A Challenge to Occupational Culture in Mines. Doctoral Dissertation, Faculty of Social Science and Humanities, University of the Witwatersrand, Johannesburg, South Africa, 2009.

32. Mercier, L.; Gier, J. Reconsidering women and gender in mining. Hist. Compass 2007, 5, 995-1001. [CrossRef]

33. D'Souza, M.S.; Karkada, S.N.; Somayaji, G. Factors associated with health-related quality of life among Indian women in mining and agriculture. Health Qual. Life Outcomes 2013, 11, 9. [CrossRef]

34. Botha, D.; Cronjé, F. Women in mining: A conceptual framework for gender issues in the South African mining sector. S. Afr. J. Labour Relat. 2015, 39, 10-37.

35. Botha, D. Women in mining still exploited and sexually harassed. SA J. Hum. Resour. Manag. 2016, 14, 1-12. [CrossRef] 
36. Lahiri-Dutt, K. Do Women Have a Right to Mine? Can. J. Women Law 2019, 31, 1-23. [CrossRef]

37. von der Goltz, J.; Barnwal, P. Mines: The local wealth and health effects of mineral mining in developing countries. J. Dev. Econ. 2019, 139, 1-16. [CrossRef]

38. Sahoo, M. Mining and Social Capital: A Micro-analysis from Odisha, India. J. Popul. Soc. Stud. 2020, 29, 100-117. [CrossRef]

39. Wegenast, T.; Beck, J. Mining, rural livelihoods and food security: A disaggregated analysis of sub-Saharan Africa. World Dev. 2020, 130, 104921. [CrossRef]

40. World Bank. World Development Indicators; World Bank: Washington, DC, USA, 2020.

41. Monteiro, N.B.R.; da Silva, E.A.; Neto, J.M.M. Sustainable development goals in mining. J. Clean. Prod. 2019, 228, 509-520. [CrossRef]

42. Buss, D.; Rutherford, B.; Stewart, J.; Côté, G.E.; Sebina-Zziwa, A.; Kibombo, R.; Lebert, J. Gender and artisanal and small-scale mining: Implications for formalization. Extr. Ind. Soc. 2019, 6, 1101-1112. [CrossRef]

43. Bashwira, M.R.; Cuvelier, J. Women, mining and power in southeastern Democratic Republic of Congo: The case of Kisengo. Extr. Ind. Soc. 2019, 6, 960-967. [CrossRef]

44. Hirons, M. How the Sustainable Development Goals risk undermining efforts to address environmental and social issues in the small-scale mining sector. Environ. Sci. Policy 2020, 114, 321-328. [CrossRef]

45. Morales, S. Digging for Rights: How Can International Human Rights Law Better Protect Indigenous Women from Extractive Industries? Can. J. Women Law 2019, 31, 58-90. [CrossRef]

46. Johnsson-Latham, G. Initial study of lifestyles, consumption patterns, sustainable development and gender: Do women leave a smaller ecological footprint than men? In Report from the Swedish Ministry of Sustainable Development; Ministry of Sustainable Development: Stockholm, Sweden, 2006.

47. Toro, F.; Serrano, M.; Guillen, M. Who Pollutes More? Gender Differences in Consumptions Patterns, Research Institute of Applied Economics Working Paper 2019/06 1/48 pág. 2019. Available online: http://www.ub.edu/irea/working_papers/2019 /201906.pdf (accessed on 14 December 2020).

48. Hendriks, S. The role of financial inclusion in driving women's economic empowerment. Dev. Pract. 2019, 29, 1029-1038. [CrossRef]

49. Bent, B.B. The Impact of Microfinance on Poverty Reduction and Women Empowerment. In Rais Collective Volume-Economic Science; Scientia Moralitas Research Institute: Frankfurt, Germany, 2019; pp. 72-86.

50. Wu, J.; Li, Y.; Zhang, D. Identifying women's entrepreneurial barriers and empowering female entrepreneurship worldwide: A fuzzy-set QCA approach. Int. Entrep. Manag. J. 2019, 15, 905-928. [CrossRef]

51. Anindya, K.; Lee, J.T.; McPake, B.; Wilopo, S.A.; Millett, C.; Carvalho, N. Impact of Indonesia's national health insurance scheme on inequality in access to maternal health services: A propensity score matched analysis. J. Glob. Health 2020, 10, 010429. [CrossRef] [PubMed]

52. Raimi, M.; Suleiman, R.M.; Odipe, O.E.; Tolulope, S.J.; Modupe, O.; Olalekan, A.S.; Christianah, M.B. Women Role in Environmental Conservation and Development in Nigeria. Ecol. Conserv. Sci. 2019, 1, 42-57. [CrossRef]

53. Pesaran, M.H.; Shin, Y.; Smith, R.J. Bounds testing approaches to the analysis of level relationships. J. Appl. Econom. 2001, 16, 289-326. [CrossRef]

54. Arya, S.L.; Samra, J.S.; Mittal, S.P. Rural women and conservation of natural resources: Traps and opportunities. Gend. Technol. Dev. 1998, 2, 167-185. [CrossRef]

55. Mago, P.; Gunwal, I. Role of Women in Environment Conservation. 2019. Available online: https://papers.ssrn.com/sol3/papers. cfm?abstract_id=3368066 (accessed on 18 December 2020).

56. Singh, S.; Dixit, S. Diverse Role of Women for Natural Resource Management in India. Asian J. Agric. Ext. Econ. Sociol. 2020, $38,27-32$.

57. Jones, M.S.; Solomon, J. Challenges and supports for women conservation leaders. Conserv. Sci. Pract. 2019, 1, e36. [CrossRef]

58. Asi, Y.M.; Williams, C. Equality through innovation: Promoting women in the workplace in low-and middle-income countries with health information technology. J. Soc. Issues 2020, 76, 721-743. [CrossRef]

59. Yue, S.; Munir, I.U.; Hyder, S.; Nassani, A.A.; Abro, M.M.Q.; Zaman, K. Sustainable food production, forest biodiversity and mineral pricing: Interconnected global issues. Resour. Policy 2020, 65, 101583. [CrossRef]

60. Nassani, A.A.; Awan, U.; Zaman, K.; Hyder, S.; Aldakhil, A.M.; Abro, M.M.Q. Management of natural resources and material pricing: Global evidence. Resour. Policy 2019, 64, 101500. [CrossRef]

61. Khan, H.U.R.; Islam, T.; Yousaf, S.U.; Zaman, K.; Shoukry, A.M.; Sharkawy, M.A.; Hishan, S.S. The impact of financial development indicators on natural resource markets: Evidence from two-step GMM estimator. Resour. Policy 2019, 62, 240-255. [CrossRef]

62. Dogan, E.; Altinoz, B.; Tzeremes, P. The analysis of 'Financial Resource Curse' hypothesis for developed countries: Evidence from asymmetric effects with quantile regression. Resour. Policy 2020, 68, 101773. [CrossRef]

63. Khan, H.U.R.; Zaman, K.; Usman, B.; Nassani, A.A.; Aldakhil, A.M.; Abro, M.M.Q. Financial management of natural resource market: Long-run and inter-temporal (forecast) relationship. Resour. Policy 2019, 63, 101452. [CrossRef]

64. Sinha, A.; Sengupta, T. Impact of natural resource rents on human development: What is the role of globalization in Asia Pacific countries? Resour. Policy 2019, 63, 101413. [CrossRef]

65. Asif, M.; Khan, K.B.; Anser, M.K.; Nassani, A.A.; Abro, M.M.Q.; Zaman, K. Dynamic interaction between financial development and natural resources: Evaluating the 'Resource curse' hypothesis. Resour. Policy 2020, 65, 101566. [CrossRef] 
66. Baum, S.; Benshaul-Tolonen, A. Structural Transformation, Extractive Industries and Gender Equality. 2019. Available online: https: / / papers.ssrn.com/sol3/papers.cfm?abstract_id=3464290 (accessed on 19 December 2020).

67. Ibrahim, A.F.; Rutherford, B.; Buss, D. Gendered "choices" in Sierra Leone: Women in artisanal mining in Tonkolili District. Can. J. Afr. Stud. 2020, 54, 157-176. [CrossRef]

68. Shafiei, A.; Maleksaeidi, H. Pro-environmental behavior of university students: Application of protection motivation theory. Glob. Ecol. Conserv. 2020, 22, e00908. [CrossRef]

69. Xie, J.; Nozawa, W.; Managi, S. The role of women on boards in corporate environmental strategy and financial performance: A global outlook. Corp. Soc. Responsib. Environ. Manag. 2020, 27, 2044-2059. [CrossRef]

70. Islam, M.; Managi, S. Green growth and pro-environmental behavior: Sustainable resource management using natural capital accounting in India. Resour. Conserv. Recycl. 2019, 145, 126-138. [CrossRef]

71. Yasmin, N.; Grundmann, P. Home-cooked energy transitions: Women empowerment and biogas-based cooking technology in Pakistan. Energy Policy 2020, 137, 111074. [CrossRef]

72. Purnamawati, I.; Adnyani, N. Performance evaluation of microfinance institutions and local wisdom-based management concept. Manag. Sci. Lett. 2020, 10, 143-152. [CrossRef]

73. Montanari, B.; Bergh, S.I. Why women's traditional knowledge matters in the production processes of natural product development: The case of the Green Morocco Plan. In Women's Studies International Forum; Elsevier: Amsterdam, The Netherlands, 2019; Volume 77, p. 102275.

74. Bleischwitz, R.; Dittrich, M.; Pierdicca, C. Coltan from Central Africa, international trade and implications for any certification. Res. Policy 2012, 37, 19-29. [CrossRef]

75. Hilson, G.; Van Bockstael, S.; Sauerwein, T.; Hilson, A.; McQuilken, J. Artisanal and small-scale mining, and COVID-19 in sub-Saharan Africa: A preliminary analysis. World Dev. 2021, 139, 105315. [CrossRef]

76. Peterman, A.; Schwab, B.; Roy, S.; Hidrobo, M.; Gilligan, D.O. Measuring women's decision making: Indicator choice and survey design experiments from cash and food transfer evaluations in Ecuador, Uganda and Yemen. World Dev. 2021, 141, 105387. [CrossRef]

77. IPU. Women in Politics: 2021; Inter-Parliamentary Union: Geneva, Switzerland, 2021; Available online: https://www.ipu.org/ women-in-politics-2021 (accessed on 13 June 2021). 